\title{
Soundscape: Musik dan Lingkungan Hidup
}

\author{
Daniel de Fretes \\ Mahasiswa S2 Penciptaan dan Pengkajian Seni, Institut Seni Indonesia Yogyakarta \\ E-mail: danieldf1684@gmail.com; Tel.: +6289506641947
}

\begin{abstract}
Former researchers have formulated that music is a manifestation of an intimate encounter between man and the universe. However, today's civilization urges people to exploit the universe in order to achieve the goal of modernity. Ecology offers a variety of discourses on the interconnection of humans and the universe that are connected to each other. This perspective also exists in music, the soundscape. This paper is a literature review that put forward the ecological discourse of music as an alternative in the study and the work of music. Soundscape provides a discourse for raising human awareness of the voices in their environment as an evaluative process in order to achieve a sustainable society.
\end{abstract}

Keywords: music; soundscape; society

\begin{abstract}
Abstrak
Pada pemikir terdahulu telah merumuskan bahwa musik adalah manifestasi dari suatu pertemuan yang intim antara manusia dengan alam semesta. Namun, peradaban masa kini mendesak manusia untuk mengeksploitasi alam semesta guna mencapai tujuan modernitas. Ekologi menawarkan berbagai wacana mengenai interkoneksi manusia dan alam semesta yang bersifat jaringan keterhubungan antara satu dengan yang lainnya. Perspektif ini hadir pula dalam musik, yaitu soundscape. Tulisan ini merupakan kajian pustaka yang mengedepankan wacana ekologi musik sebagai suatu alternatif dalam kajian maupun karya musik. Soundscape memberikan suatu wacana untuk meningkatkan kesadaran manusia terhadap suara-suara di lingkungan hidupnya sebagai suatu proses evaluatif guna mencapai tatanan masyarakat yang berkelanjutan.
\end{abstract}

Kata kunci: musik; soundscape; sosial

\section{Pengantar}

Musik adalah realitas jagat raya yang diilhami manusia. Ini telah dirumuskan oleh para filsuf masa lampau yang menganggap bahwa musik merupakan jelmaan dari alam semesta. Alam memiliki kekayaan bunyibunyian dan irama musikal yang khas. Manusia adalah mahluk yang selalu belajar dari sifat alami lingkungannya seperti keharmonisan, keseimbangan simetrikal, rasa kebersamaan hingga penyatuan diri. Bunyi gemercik riak yang mengaliri sungai, deru ombak yang menyapu lautan, gaung angin yang menembus pepohonan, tetesan embun yang menerpa dedaunan, rintik hujan hingga gemuruh petir yang menyambar hamparan sawah, secara keseluruhan merupakan gejala alam yang memiliki suara dan irama yang hidup. Begitu pula dengan denyut jantung, desahan nafas, hingga pita suara manusia yang secara alami menghasilkan bunyi-bunyian. Ini menggambarkan keintiman manusia dan alam semesta dengan musik sebagai suatu kesatuan yang tidak dapat dipisahkan, yang keseluruhannya selalu bertransformasi sesuai dengan perkembangan peradaban manusia dari masa ke masa. Suka Hardjana menggambarkan suatu proses pertemuan antara manusia dan alam yang menghasilkan karya seni musik, ketika bunyi asli yang ber- 
sumber pada alam diartikulasikan atau diolah manusia menjadi bunyi buatan yang mengandung nilai artistik, sehingga baik bunyi alam yang asli maupun bunyi buatan hasil kerja manusia menjadi bahasa seni, yaitu musik (Hardjana, 1983: 58-59)

Pada peradaban masa kini, arus modernitas telah melebur di dalam diri manusia sehingga segala aktivitas kehidupan cenderung mengarah pada penyeragaman capaian dan tujuan, sebut saja kebutuhan materi yang tidak ada habisnya. Pemahaman bahwa manusia adalah sang penakluk bumi dan seluruh isinya melegitimasi eksploitasi alam yang begitu masif sehingga upayaupaya tersebut justru berdampak kerusakan dan ketidakseimbangan alam hingga keterasingan umat manusia. Kemelut pertumbuhan industri-industri besar, pengeboran minyak secara semrawut, pengerusakan hutan dan lahan pertanian, eksplorasi sumber kekayaan laut serta kampanye pola hidup dan budaya populer ala negara-negara maju memicu ketidakseimbangan kebutuhan manusia dengan ketersediaan sumber daya alam. Sebagian kecil pihak berusaha untuk mencari pemecahan masalah ini dengan mengedepankan kesadaran akan lingkungan hidup, namun upaya mereka masih mencaricari celahnya di tengah kepentingankepentingan besar pihak-pihak tertentu.

Di tengah krisis peradaban di era globalisasi ini dengan berbagai anomali arus teknologi informasi, sejumlah pemikiran berupaya untuk menghadirkan paradigma baru bagi kelangungan hidup umat manusia. Salah satunya adalah ekosentris yakni suatu pemikiran yang berdasarkan pada oikos (Yunani) yang artinya rumah, yakni rumah dimana manusia itu hidup dan menetap di dalamnya. Ekosentris bersifat holistik yaitu dunia sebagai suatu keseluruhan yang terpadu, bukan suatu kumpulan yang terpisah-pisah. Kesadaran ekologis berarti mengakui kesalingtergantungan fundamental terhadap semua fenomena dan fakta bahwa sebagaimana individu dan masyarakat, manusia terlekat dan tergantung secara mutlak dalam proses siklik alam semesta.

Paradigma ini terkait dengan filosofis post-modern konstruktivis. Postmodern konstruktif adalah gerakan postmodern kategori pertama dalam klasifikasi yang dibuat oleh Bambang Sugiharto, yakni pemikiran yang merevisi kemodernan yang cendrung kembali ke pola berfikir pramodern - metafisika New-Age di wilayah mistiko-mistis. Aliran ini muncul dari disiplin Fisika Baru dengan semboyan "holisme", dengan tokoh-tokoh seperti: F. Capra, J. Lovelock, Garry Zukav, Prigogine, dan tokoh lainnya (Sugiharto, 1996: 30).

Paradigma tersebut pada awalnya bergerak melalui akar rumput yakni gerakan 'ekologi dalam'. Aliran ini digagas oleh Arne Naess, filsuf asal Norwegia pada awal tahun 70-an dengan memunculkan perbedaan 'ekologi dalam' dengan 'ekologi dangkal'. Ekologi dangkal bersifat antroposentris, memandang manusia berada diluar alam, sebagai satu-satunya sumber nilai dan alam sebagai alat atau hanya memiliki nilai guna. Ekologi dalam tidak memisahkan manusia dari lingkungan alam-nya, dengan melihat dunia sebagai sebagai suatu jaringan fenomena yang saling berhubungan dan saling tergantung satu sama lain secara fundamental, bukan sebagai kumpulan objek yang terpisah. Ekologi dalam mengakui nilai intristik semua makhuk hidup dan memandang manusia tak lebih dari satu untaian dalam jaringan kehidupan (Capra, 1997: 6-7).

Paradigma ini berusaha hadir untuk mengatasi kemelut modernitas dengan paradigma mekanistik-deterministikmatrealistik ala Descartes, Darwin, filsuffilsuf modern lainya yang membentuk fondasi budaya industri modern. Ekologi memandang manusia, segala mahluk hidup, dan alam semesta sebagai satu kesatuan 'holistik' jaringan kehidupan. 
Kemunculan paradigma ini tidaklah mudah untuk mencapai konsensus atau kesepakakatan dari berbagai pihak yang terkait, seperti yang disyaratkan oleh Kuhn sebagai bagian dari proses revolusi paradigma. Pihak-pihak yang memiliki kepentingan ekonomi dan politik secara global tentunya akan mempertahankan modernitas dengan globalisasi informasi teknologi sebagai basis ideologi ekonomi. Namun demikian, sebagian lain tampaknya mulai menyadari keterbatasan manusia dan ketergantungannya terhadap lingkungan hidupnya. Pandangan bahwa manusia sebagai bagian dari jaringan kehidupan tampaknya menjadi hal yang mendesak untuk disadari oleh umat manusia guna menyelamatkan lingkungan hidup dan menselaraskan diri dengannya.

\section{Pembahasan}

Ekologi memandang manusia sebagai entitas yang tidak dapat dipisahkan dengan lingkungan hidupnya. Pada bagian selanjutnya akan dibahas prinsip-prinsip ekologi dalam kaitannya dengan musik, perjalanan soundscape dan soundscape dalam khidupan manusia sehari-hari.

\section{Ekologi dalam Musik}

Pada prinsipnya, ekologi dalam musik tercermin dalam musik-musik di era kuno peradaban manusia, dimana pada saat itu manusia masih bergantung dengan alam dengan prikihidupan manusia bersifat kosmosentris. Musik dalam bentuk ritual sering sekali dianggap sebagai cerminan alam semesta, selayaknya suara ombak yang bergulung di lautan dan suara gemuruh petir di angkasa. Masyarakat Yunani, sebagai embrio pengetahuan musik di belahan dunia barat mempercayai bahwa musik adalah pemberian dari dewa-dewa sebagai hadiah pada umat manusia. Keberadaan musik juga memberikan kontribusi yang berarti bagi perkembangan ilmu pengetahuan, seperti yang dilakukan oleh Pitagoras melalui penelitian tetrachord-nya, dalam usaha membuktikan kebenaran angka-angka sebagai realitas alam semesta. Demikian kita dapat melihat, bagaimana musik memiliki keteraturan dari sistem ketetapan alam semesta yang membuatnya terjalin dalam suatu sistem kosmologi. Ekologi bukanlah menentang kosmologi, namun kehadiran ekologi didasari dengan kesadaran, seperti yang dikemukaan oleh Varella dan Maturana sebagai kognisi, yang tentunya mengalami perkembangan dan kemandirian seiring dengan perkembangan pengetahuan manusia dari masa ke masa. Konsep kognisi Varella \& Maturana berdasarkan pada Teori kognisi Santiago, yaitu suatu proses mengetahui dengan proses kehidupan yang sebenarnya. Menurut Varella \& Maturana, kognisi adalah aktivitas yang terlibat dalam pengembangbiakan mandiri dan pengekalan mandiri jaringan-jaringan hidup (Capra, 2003: 34).

Kesadaran ekologi dalam musik sesungguhnya telah mengakar pada masyarakat-masyarakat tradisional, yang menyadari penuh kebutuhan manusia untuk menjaga keseimbangan diri dengan alam semesta. Namun, di masyarakat modern kesadaran ini tidak lagi mendapatkan perhatian. Musik lebih banyak berpusat pada manusia sebagai penyelenggara kebudayaan, dinamika kehidupan dan perasaan manusia dan dalam perkembangannya bahkan melupakan esensi kealamiahan musik itu sendiri. Salah satu bentuk komposisi musik masa kini yang bersifat ekologis adalah soundscape. Komposisi musik ini mengambil suara-suara alam sebagai elemen-elemen yang mendasarinya, seperti suara rintik hujan, suara jangkrik di malam hari, suara aliran air sungai, suara hembusan angin di pegunungan hingga suara peradaban manusia di pedesaan maupun perkotaan. Musik soundscape digarap dengan aturanaturan komposisi konvensional, namun menggunakan bunyi-bunyian bersumber 
dari lingkungan manusia sehingga musik ini mengembalikan suara-suara yang bersumber dari lingkungan manusia tersebut kepada manusia yang mendengarkannya. Kehadiran soundscape memiliki makna natural dan ekologis, yang memberikan kesadaran bagi manusia untuk menghargai lingkungan hidup dimana ia hidup dan tinggal.

\section{Sekelumit Perjalanan Soundscape}

Istilah soundscape pertama sekali diperkenalkan oleh komponis asal Kanada, R. Murray Schafer yang juga seorang penulis, edukator musik dan environmentalis yang berkecimpung dalam bidang akustik ekologi. Istilah ini dipinjam Schafer dari geografer Michael Southworth, yang menggunakan istilah soundscape dalam artikelnya 'The Sonic Environment of Cities', kemudian Schafer mengembangkan definisi soundscape dan mengangkatnya sebagai isu internasional (Schafer, 2012:120).

Menurut Schafer, Soundscape berasal dari kata landscape, kata yang diperkenalkan oleh Petrarch, penyair Italia abad ke-14 yang berjalan ke puncak gunung untuk melihat pemandangan, sesuatu yang belum pernah dilihat sebelumnya sehingga ia mendeskripskikannya dengan kata baru 'landscape' (Schafer, 2012b:6). Schafer memperkenalkan kata soundscape untuk mendeskripsikan apa yang manusia dengar dalam kehidupan sehari-hari. Dengan demikian, soundscape atau sonic environment dapat dipahami dengan pemandangan yang berupa suara atau bunyi dalam kehidupan manusia sehari-hari.

Schafer melalui memoarnya mengemukakan hal yang melatari ide karyakaryanya, yakni pengalamannya selama 1960an sewaktu mengajar di Simon Fraser University, Vancouver yang disebutnya dekade paling berisik di abad ke-20. Gejala tersebut disebabkan oleh noise yang berasal dari suara buldozer di wilayah sekitar kampus yang sedang dalam kondisi pembangunan, suara pesawat jet yang baru saja diperkenalkan menggantikan peran pesawat turbo-prop pada penerbangan komersial, industri mobil yang memperkenalkan 'muscle car' dengan mesin mutakhir yang sangat berisik, hingga pengaruh industri hiburan yang memproduksi suara musik band rock yang cenderung mendorong volume pada level ratusan desibel (Schafer, 2012:92). Hal ini merupakan konsekuensi kemajuan peradaban yang tidak dapat dihindarkan, dimana rekonstruksi perekonomian global terjadi pasca perang dunia ke-2 di Eropa dan Amerika yang berkaitan dengan keberadaan para pengungsi serta konteks kultural di Kanada pada saat itu. Salah satu dampaknya adalah perubahan iklim yang menjadi cukup panas pada saat musim dingin, sehingga peran lapisan jendela atau double glassing sebagai pemanas dan pelindung badai di rumah-rumah penduduk menjadi tidak berfungsi. Ini menyebabkan semakin jelas terdengarnya suara-suara dari kendaraan bermotor dan suara noise lainnya di setiap rumah penduduk. Lingkungan urban telah didesain untuk mengakomodir kendaraan bermotor, klakson, peluit, sirene, pesawat terbang, sehingga noise yang dihasilkan mesin-mesin ini telah diterima sebagai hal yang tak terhindari. Schafer dalam perenungannya berusaha mencari penyelesaian masalah ini, baik melalui organisasi anti-noise yang menurutnya tidak maksimal dalam menyuarakan aspirasi serta perannya sebagai pengajar di Simon Fraser University melalui penelitian-penelitian yang berfokus pada polusi noise.

Penelitian Schafer berkembang dengan menggunakan pendekatan yang berbeda terhadap suara lingkungan, yakni meningkatkan fokus dari noise menuju soundscape. Ia menunjukkan bagaimana semua suara pada saat ini kemudian akan menjadi suara di masa lalu dan mempertanyakan: akankah ada museum untuk suara-suara yang telah hilang? Schafer lalu mengumpulkan referensi untuk suara- 
suara tertentu yang ditemukan dalam deskripsi dari tempat dan waktu yang berbeda. Menurutnya, kesempatan untuk mengkaji suara-suara di masa lalu dan masa kini, entah itu berguna atau tidak berguna, indah atau buruk, menarik atau membosankan, setidaknya hal itu menyatukan aspek praktik dan estetis suara, mengizinkan kita untuk mengkaji dan menjelaskan lingkungan akustik melalui kehidupan kita sehari-hari (Schafer, 2012b: 67). Pada tahun 1975, Schafer melalui serangkaian penelitiannya melalui World Soundscape Project (WSP) mengkaji lingkungan desa-desa kecil di lima negara Eropa yang dipengaruhi oleh satu industri besar. World Soundscape Project adalah proyek penelitian dan edukasi yang didirikan R. Murray Schfer pada 1969 di Simon Fraser Unifersity. Proyek ini mendirikan lapangan studi modern yaitu akustik ekologi atau studi soundscape yang berfokus pada kekuatiran publik terhadap suara, mendokumentasikan suara lingkungan dan perubahan karakternya dan mendirikan konsep dan praktik dari desain soundscape sebagai solusi alternatif terhadap polusi suara (lihat http://thecanadaencyclopedia.ca)

Kajian ini mengungkap keunikan pola suara di setiap desa dan cara bagaimana pola suara ini mengkonstitusi kehidupan sosial di desa tersebut. Pada salah satu desa nelayan di Lesconil, Britania, terdapat jalan raya besar yang dekat dengan desa yang menghasilkan tingkat noise yang tinggi, sehingga berdampak ketakutan pada ikanikan dan membunuh industri ikan. Schafer kemudian berupaya mencari solusi melalui peran pers dan media setempat sehingga akhirnya berhasil melindungi lingkungan hidup. Penelitian Schafer mengispirasi banyak orang di seluruh dunia untuk meneliti soudscape sehingga terbentuk World Forum for Accoustic Ecology (WFAE) pada tahun 1993 di Banff, Alberta, sebagai asosiasi internasional dari organisasi- organisasi terafiliasi dan para individu di Eropa, Amerika Utara, Jepang dan Australia yang saling berbagi perhatian umum terhadap soundscape di seluruh dunia (lihat http:// wfae.proscenia.net).

Konsep-konsep yang dikemukakan Schafer, baik melalui komposisi musik, publikasi, perkuliahan dan lokakarya-nya, adalah penerapan suatu cara tertentu dalam upaya memahami elaborasi praktik dan penelitian akustik. Suara yang selama ini hanya menjadi pembahasan yang diabaikan - meskipun ia selalu hadir di alam semesta, kini menjadi suatu lapangan penelitian bagi refleksi kritis dan analitis. Schafer mengembangkan suatu fondasi yang menjadi tema besar yakni akustik ekologi atau kajian soundscape, yang kemudian dilanjutkan oleh para sarjana dan seniman lainnya untuk mendiagnosa, menginterpretasi, mengkomposisi suara, dan mempertanyakan manfaat dari soundscape atau sonic environment secara mental dan fisikal dalam lingkungan hidup manusia.

Komposisi musik environmental Schafer yang pertama adalah Music for Wilderness Lake. Karya ini digarap pada tahun 1979 untuk format 12 trombon. Schafer menyusun karya ini berdasarkan perjalanannya berperahu melintasi salah satu danau di area Madawaska dengan memperhatikan bagaimana perubahan suara sepanjang hari hingga malam. Terdapat dua sesi, Dawn dan Dusk yang dimainkan pada waktu dan tempat yang tepat pula. Dengan ide demikian, Schafer mengatasi sulitnya audiens menjangkau daerah tersebut melalui kerja sama dengan CBC Radio serta beberapa mahasiswa perfilman yang tergabung dalam Rhombus Media untuk membuat film tentang musik dan para musisi dalam karya ini (Schafer, 2012:151). Banyak sekali karya musik Schafer yang bertema environmental, beberapa diantaranya dapat ditemukan dewat streaming audio-visual di www.youtube.com seperti Hear The Sounds of Go Round dan String Quartet No.2 
"Waves". Hear The Sounds of Go Round adalah komposisi untuk paduan suara SATB ditampilkan oleh Elmer Iseler Singers, ProCoro Canada dan Vancouver Chamber Choir (konduktor: Kaspars Putnins) pada 2 febuari 2014 pada event Candaian Choral Celebration di Koerner Hall, Toronto, Canada. Komposisi musik yang digarap secara konvensional ini memiliki pesan moral melalui liriknya untuk peka mendengarkan suara di lingkungan sekitar kehidupan kita - dibeberapa bagian terdapat tiruan suara alam sangat natural melalui teknik vokal para vokalis paduan suara secara bergantian maupun bersamaan. Quartet No.2 "Waves" dimainkan oleh The Oxford String Quartet, dimana 2 biola, viola dan cello memainkan melodi yang meniru gelombang sonic environment, pola-pola kromatis serta karakter teknik glisando, tremolo dan aksentuasi dengan intensitas yang tinggi dan tempo yang cepat mewarnai karya musik atonal ini.

\section{Soundscape di sekitar kita}

Istilah soundscape masih sangat asing di telinga orang Indonesia, baik awam, praktisi maupun akademisi musik. Beberapa praktisi dan akademisi juga membicarakannya namun sepertinya persepsi soundscape sebagai komposisi musik diidentifikasikan dengan musik dengan media elek-tronik atau digital. Apabila kita mengacu pada konsep yang dikemukan Schafer, kita akan menemukan bahwa komposisi musik soundscape adalah komposisi yang digarap dengan media musik konvensional dengan ide-ide musikal yang didasari pada pemandangan suara di suatu lingkungan tertentu, baik yang alami maupun urban. Instrumen musik konvensional mungkin tidak harus menjadi patokan untuk menggarap soundscape, peran instrumen musik yang non-konvensional maupun media elektronik dapat juga dieksplorasi untuk mengungkapkan ide-ide musikal. Namun demikian, satu hal yang harusnya dilakukan sebelum sampai ke ide-ide musikal adalah studi lingkungan terlebih dahulu, hal itu dapat berupa observasi soundscape di suatu lingkungan hidup hingga penelitian menuju studi environmental yang lebih lanjut.

Shin Nakagawa memberikan gambaran mengenai soundscape melalui studinya di Bali dan Yogyakarta. Bertolak pada konsep Schafer, Nakagawa mengemukakan bahwa soundscape atau pemandangan bunyi membahas bagaimana bunyi-bunyian mengambil bagian dalam konteks suara dalam suatu lingkungan dengan pemandangan suara yang baginya adalah ide dalam bentuk non-visual, yakni pemandangan akustik atau pemandangan untuk telinga (Nakagawa, 2000: 106). Dalam perjalanannya ke pura di sebuah desa daerah pegunungan Bali, ia menggambarkan bagaimana bunyi serangga menyelimuti area tanah lapang atau kebun, suara gong yang lirih saat mendekati pura, dan suara gamelan yang keras di sekitar areal upacara. Nakagawa mengungkapkan bahwa apa yang ia dengar merupakan objek visual di angkasa terdengar dimana-mana, sehingga bunyi-bunyi tersebut membentuk suara lingkungan dalam suatu ruang (Nakagawa, 2000: 105).

Nakagawa mengemukakan studi soundscape-nya di Yogyakarta melalui buku yang ditulisnya tahun 1992 dan pengalamannya mengajar di ISI Yogyakarta pada tahun 1997. Analisis Nakagawa hampir sama dengan analisis R. Anderson Sutton, profesor dari Universitas Wisconsin, Amerika Serikat yang pada tahun 1996 menulis artikel tentang soundscape di Jawa, dimana keduanya meletakkan soundscape Jawa dalam konteks kebudayaan, namun dengan sasaran yang berbeda. Sutton meneliti tentang lagu-lagu populer yang diputar dengan volume keras di toko kaset, suara keras melalui pengeras suara di pesta pernikahan, dan suara azan di masjid yang menggunakan pengeras suara. Menurutnya, seluruh kota di Jawa diselimuti oleh suara-suara dari pengeras suara ini yang 
secara kualitas suara sangat buruk dan hampir rusak (distorted), sehingga membentuk karakter soundscape Jawa. Sutton menunjukkan alasan pokok yang berkaitan dengan konteks kultural masyarakat Jawa: kesenangan orang Jawa terhadap keramaian dan penggunaan teknologi modern tanpa kontrol yang berkaitan prestise atau simbol status masyarakat Jawa. Nakagawa meneliti bunyibunyi akustik dalam kehidupan masyarakat di Yogyakarta sehari-hari, antara lain bunyi kentongan bambu disaat ronda malam, bunyi-bunyi khas pedagang di setiap penjuru kota seperti mangkuk penjual bakso, kentongan penjual siomay, lonceng kecil penjual es krim dan lain sebagainya. Nakagawa mengemukakan bahwa soundscape di Yogyakarta berkaitan dengan budaya anti konflik dan status sosial yang melekat di masyarakat Jawa serta rasa aman masyarakat melalui suara keramaian lingkungan baik siang maupun malam hari yang juga tercermin musik gamelan - disebutnya 'miniatur soundscape jawa' (Nakagawa, 2000: 126-135).

Soundscape di Yogyakarta, seperti yang diungkapkan Nakagawa dan Sutton, adalah pemandangan akustik sehari-hari yang didengar oleh masyarakat Yogyakarta. Mungkin sebagaian besar masyarakat tidak mempermasalahkan hal itu karena suarasuara tersebut sesuai dengan konteks budaya setempat. Namun berberbeda halnya dengan konsekuensi psikologis dari setiap individu masyarakat yang sebenarnya tidak disadari. Penulis yang pernah menetap di berbagai kota seperti Medan, Jakarta, Yogyakarta, Purwokerto, Surabaya dan Makassar merefleksikan pemandangan akustik di setiap kota yang memiliki karakter atau landmarknya tersendiri. Yogyakarta mungkin tidak sebising Jakarta dan kota lainnya dalam hal noise ala kehidupan urban, namun konteks budaya anti konflik yang cenderung membiarkan polusi suara yang dalam tingkatan tertentu juga merugikan masyarakat. Ini terutama berkaitan dengan kendaraan bermotor yang sengaja disetel dengan noise tinggi dengan tujuan-tujuan seperti prestise, gaya hidup dan terkadang kampanye politik maupun demonstrasi- bahkan pihak yang berwajib pun tidak mengambil tindakan apapun. Fungsi pengeras suara dan aturan yang baku dalam penggunaannya juga harus menjadi perhatian penting, karena dampak yang dihasilkan tentu merugikan kesehatan masyarakat, baik disadari atau tidak.

Suka Hardjana mengemukakan bahwa bunyi sebagai alam sangat sugestif terhadap manusia dimana manusia tidak dapat menghindar dari alam demikian juga manusia tidak dapat menghindar dari bunyi, sehingga manusia terjebak dalam sugesti bunyi yang bersifat 'relatif' dalam memilih bahasa musikal yang mereka anggap sesuai dan baik (Hardjana, 1983:53). Sugesti bunyi mengindikasikan suatu proses adaptasi manusia dengan bunyi-bunyian yang ada di lingkungan hidupnya, baik itu menerima ataupun menolaknya. Suara berisik knalpot sepeda motor atau suara mesin sepeda motor 2-tak bagi sebagian orang sangat menarik, namun justru sangat mengganggu bagi kebanyakan orang. Demikian juga suara derap laju kereta api di stasiun, sangat menarik bagi kita yang ingin berpetualang, namun menjenuhkan bagi petugas kereta api ataupun penduduk yang menetap di pinggir rel kereta. Bagaimana dengan mereka yang tinggal di pinggir jalan tol? Atau di pinggir jalan utama antar propinsi?

Sebagian masyarakat kita tidak mampu memilih di lingkungan mana ia akan menetap. Mereka menjalani kehidupan sehari-hari dengan apa adanya. Mungkin bagi sebagian besar masyarakat (khususnya negara berkembang), permasalahan ekonomi-lah yang justru dipandang lebih krusial dibandingkan dengan sekedar permasalahan suara-suara di lingkungan mereka. Kesadaran lingkungan hidup baru dapat dirasakan apabila terjadi peringatan akan bencana alam yang mengancam lingkungan mereka. Suara lingkungan hanya menjadi norma setempat yang dikontekskan 
dengan budaya saling menghargai, tenggang rasa ataupun tepo seliro. Kesadaran suara lingkungan atau sonic environment menjadi tantangan bagi masyarakat, tanpa kesadaran baik secara individu maupun kolektif, keseimbangan sonic environment tidaklah mungkin tercapai. Pentingnya kesadaran lingkungan hidup atau kesadaran ekologi, khususnya sonic environment merupakan tanggung jawab bersama masyarakat yang mendesak untuk dikedepankan dalam kehidupan sehari-hari.

Fritjof Capra mengusulkan wacana yang disebutnya "ekological literacy" atau dapat dipahami dengan istilah "melek ekologi", yaitu memahami prinsip-prinsip pengaturan komunitas-komunitas ekologis atau ekosistem-ekosistem dan menggunakannya untuk membentuk komunitaskomunitas manusia yang berkelanjutan (Capra, 1997: 297). Kesadaran ekologi merupakan inti dari pemahaman sistemik yang holistik terhadap kehidupan dengan memahami bahwa pola dasar organisasi alam semesta adalah jaringan yang hidup. Hal ini menunjukkan bahwa manusia adalah salah satu dari sekian banyak mahluk hidup yang menempati alam semesta, dimana segala unsur tidak terpisah dan saling berhungan satu dengan yang lain dalam suatu mata rantai jaringan kehidupan. Kesadaran ekologi merupakan tanggung jawab manusia, baik individu, golongan maupun masyarakat di tengah peradaban global masa kini. Peran serta para akademisi untuk membangun bingkai kesadaran ekologis masyarakat sangatlah dibutuhkan, baik melalui kajian soundscape, desain sonic environment, maupun perencanaan ekodesain terhadap permasalahan sosial lainnya yang mengkristal dalam peradaban manusia masa kini guna membentuk masyarakat yang berkelanjutan.

\section{Penutup}

Kesadaran ekologi yang dikedepankan oleh para pemikir masa kini berupaya untuk membawa manusia pada kenyataan bahwa manusia tidak hidup sendiri di alam ini, bukan juga sang penakluk yang bebas mengeksploitasi lingkungan hidupnya, namun sebagai bagian dari jaringan mata rantai dari sistem kehidupan di alam semesta. Soundscape-disiplin akustik ekologi yang mengedepankan keseimbangan suara-suara di lingkungan hidup merupakan upaya untuk memberikan suatu desain suara lingkungan atau sonic environment, menjaga, memelihara dan mengembangkan-nya dalam suatu jaringan kehidupan yang sistemik. Adapun komposisi musik, kajian, artikel dan publikasi yang bergerak dalam wilayah soundscape memberikan suatu wacana yang berharga untuk meningkatkan kesadaran manusia terhadap suara-suara di lingkungan hidupnya sehingga terjadi keharmonisan antara umat manusia dan suara lingkungannya

\section{Referensi}

\section{Buku dan Jurnal}

Capra, Fritjof. 1997. The Web of Life: A New Life Understandings of Living Systems, Doubleday, New York.

Capra, Fritjof. 2003. The Hidden Connections, Doubleday, New York.

Hardjana, Suka. 1983. Estetika Musik, Departemen Pendidikan dan Kebudayaan Direktorat Jendral Pendidikan Dasar dan Menengah, Jakarta.

Kuhn, Thomas S. 1996. The Structure of Scientific Revolutions - Third Edition, The University of Chicago Press, Chicago \& London.

Nakagawa, Shin. 2000. Musik dan Kosmos: Sebuah Pengantar Etnomusikologi, Yayasan Obor Indonesia, Jakarta.

Schafer, R. Murray. 2012. My Life on earth and elsewhere, The Porcupine's Quill, Ontario.

Schafer, R. Murray. 2012b. 'Soundscape Studies: The Early Day and The Future', Soundscape: The Journal of Acousti 
Ecology Vol. 12 No. 1, Departement of Radio, TV \& Digital Media South Illionis University, Carbondale.

Schafer, R. Murray. 1994. Our Sonic Environment and The Soundscape: The Tuning of The world, Destiny Books, Rochester.

Sugiharto, Bambang. 1996. Postmodernisme: Tantangan Bagi Filsafat, Kanisius, Yogyakarta.

\section{Webtografi}

http://thecanadaencyclopedia.ca/en/article/world-soundscape-project (diakses pada 23 Juni 2015, 00.30 wib)

http://wfae.proscenia.net (diakses pada 23 Juni 2015, $00.30 \mathrm{wib}$ )

https://www.youtube.com/watch?v=ZvhSq9 fXU9g\&in-

dex=4\&list=PL1ca6p_Q1IYc4cm93YeCb1IMdkW-bshLd (diakses pada 27 Juni 2015, $04.10 \mathrm{wib})$

https://www.youtube.com/watch?v=PS9JQx LUGrQ\&index=3\&list=PL1ca6p_QIIYc4cm93 YeCb1IMdkW-bshLd (diakses pada 27 Juni 2015, 04.15 wib) 